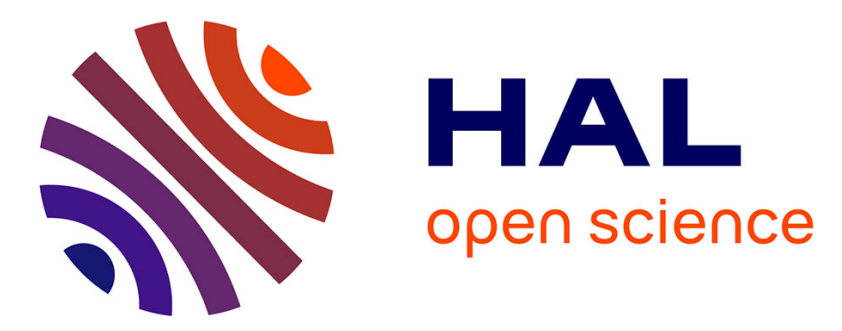

\title{
Comment on "Tectonic record of strain buildup and abrupt coseismic stress release across the northwestern Peru coastal plain, shelf, and continental slope during the past 200 kyr" by Jacques Bourgois et al.
} Kevin Pedoja, Luc Ortlieb, T. J. Devries, J. Machare, Laurence Audin, V. Regard

\section{To cite this version:}

Kevin Pedoja, Luc Ortlieb, T. J. Devries, J. Machare, Laurence Audin, et al.. Comment on "Tectonic record of strain buildup and abrupt coseismic stress release across the northwestern Peru coastal plain, shelf, and continental slope during the past $200 \mathrm{kyr}$ " by Jacques Bourgois et al.. Journal of Geophysical Research, 2011, 116, pp.B09401. 10.1029/2011JB008321 . insu-00681373

\section{HAL Id: insu-00681373}

https://hal-insu.archives-ouvertes.fr/insu-00681373

Submitted on 3 Mar 2021

HAL is a multi-disciplinary open access archive for the deposit and dissemination of scientific research documents, whether they are published or not. The documents may come from teaching and research institutions in France or abroad, or from public or private research centers.
L'archive ouverte pluridisciplinaire HAL, est destinée au dépôt et à la diffusion de documents scientifiques de niveau recherche, publiés ou non, émanant des établissements d'enseignement et de recherche français ou étrangers, des laboratoires publics ou privés. 


\title{
Comment on "Tectonic record of strain buildup and abrupt coseismic stress release across the northwestern Peru coastal plain, shelf, and continental slope during the past 200 kyr" by Jacques Bourgois et al.
}

\author{
K. Pedoja, ${ }^{1}$ L. Ortlieb, ${ }^{2}$ T. J. Devries, ${ }^{3}$ J. Machare, ${ }^{4}$ L. Audin, ${ }^{5}$ and V. Regard ${ }^{6}$ \\ Received 24 February 2011; revised 19 April 2011; accepted 25 July 2011; published 10 September 2011.
}

Citation: Pedoja, K., L. Ortlieb, T. J. Devries, J. Machare, L. Audin, and V. Regard (2011), Comment on "Tectonic record of strain buildup and abrupt coseismic stress release across the northwestern Peru coastal plain, shelf, and continental slope during the past 200 kyr" by Jacques Bourgois et al., J. Geophys. Res., 116, B09401, doi:10.1029/2011JB008321.

\section{Introduction}

[1] Based on combined analyses of onshore and offshore geological and geophysical data, Bourgois et al. [2007] interpreted the coastal segment located on the northwestern Peru forearc $\left(3^{\circ} 20^{\prime}\right.$ to $\left.7^{\circ} 30^{\prime} \mathrm{S}\right)$ to have undergone extremely high uplift rates. This was said to be due to repeated seismic events that would have occurred in the last $200 \mathrm{ka}$, and more particularly during the last $23 \mathrm{ka}$. We raise major issues concerning the (1) nature of the geomorphic features described, (2) weak attention paid to previous work and use of formerly dismissed chronological data, as well as (3) ${ }^{10} \mathrm{Be}$ ages and dates provided. These considerations lead us to question the extremely elevated and unrealistic uplift rates proposed by Bourgois et al. [2007] and to contradict the final coseismic hypothesis for the origin of coastal uplift in northern Peru.

[2] Bourgois et al. [2007] proposed a provocative interpretation for the recent tectonic history of the northwestern Peru forearc. By their interpretation, this coastal segment experienced extremely high uplift rates, mainly due to repeated seismic events that would have occurred during the last $\sim 200 \mathrm{ka}$, and more particularly the last $23 \mathrm{ka}$. Based on combined analyses of onshore and offshore geological and geophysical data collected along the northern Peru coast, their study is focused on the Cabo Blanco $\left(4^{\circ} 15^{\prime} \mathrm{S}\right)$ and PaitaIllescas $\left(5^{\circ}-6^{\circ} \mathrm{S}\right)$ areas. Here, we raise issues concerning the following: (1) climatic assumptions that the region is hyperarid, to the extent that normal meteoric erosion of modern

\footnotetext{
${ }^{1}$ Laboratoire de Morphodynamique Continentale et Côtière, CNRS, Université de Caen, Caen, France.

${ }^{2}$ Laboratoire d'Océanographie et du Climat, Expérimentation et Analyses Numériques LOCEAN, IRD-CNRS-MNHN, Université Pierre et Marie Curie, Paris, France.

${ }^{3}$ Burke Museum of Natural History and Culture, University of Washington, Seattle, Washington, USA.

${ }^{4}$ Applied Geoscience Division, Exploandes SAC, Lima, Peru.

${ }^{5}$ Institut des Sciences de la Terre, UMR 5275, CNRS/INSU/OSUG, IRD/UR/IFSTTAR, Université de Savoie, Université Joseph Fourier, Grenoble, France.

${ }^{6}$ Laboratoire Géosciences Environnement Toulouse, CNRS/IRD, Earth and Planetary Sciences Department, Université Paul Sabatier-Toulouse III, Toulouse, France.

Copyright 2011 by the American Geophysical Union. 0148-0227/11/2011JB008321
}

and fossil sea cliffs is not feasible, (2) a misunderstanding of morphochronostratigraphic markers, (3) reliance on formerly obtained chronological data which had been dismissed as unreliable, (4) weakness and questionable validation of ${ }^{10} \mathrm{Be}$ age calculations, and (5) an unrealistic interpretation of regional uplift rates, both over longer (Plio-Pleistocene) and shorter (late Quaternary) intervals of time.

\section{El Niño Heavy Rainfalls on the Northern Peru Coast}

[3] Our first issue with Bourgois et al. [2007] concerns the regional climate: they argue it exhibits a level of hyperaridity comparable to that of the Atacama Desert. From this assumption, Bourgois et al. [2007] postulate that superficial morphological features and cliff characteristics in northwestern Peru are essentially unweathered and relate only to marine erosion and wave action. This area is in a transitional climatic zone between the Sechura Desert $\left(6^{\circ}-4^{\circ} \mathrm{S}\right)$ and the subarid coastal desert of southern Ecuador, regarded as semiarid on both climatological and botanical grounds [Schwerdfeger, 1976]. The mean interannual rainfall at Cabo Blanco $\left(4^{\circ} 14^{\prime} \mathrm{S}\right)$ is only a few $\mathrm{mm} / \mathrm{yr}$, but the whole region is subjected to irregular and torrential rains which generally fall in the four first months of the year [e.g., Schütte, 1968]. The region registers one of the highest deviations from average precipitation recorded on Earth: an anomaly of up to $9000 \%$ was recorded in 1997-98 at Talara [Richter, 2005]. This rainfall regime played a major role in the original definition of the El Niño phenomenon [e.g., Carranza, 1891] and an abundant literature documents the occurrence of such rainfalls (for the penultimate century) [Spruce, 1864; Eguiguren, 1894]. Often described as the "heartland" of the El Niño phenomenon [e.g., Quinn et al., 1987], this area cannot be characterized as hyperarid, and hence exempt from meteoric erosion. On the contrary, the occurrence of infrequent but heavy rainfalls on a rather arid landscape produces dramatic erosive actions (see Figure 1).

\section{Meteoric Erosion Versus Wave Action to Explain the Notches in Cabo Blanco}

[4] Bourgois et al. [2007] stated that the sequence of notches visible in the cliffs at Cabo Blanco and immediately 


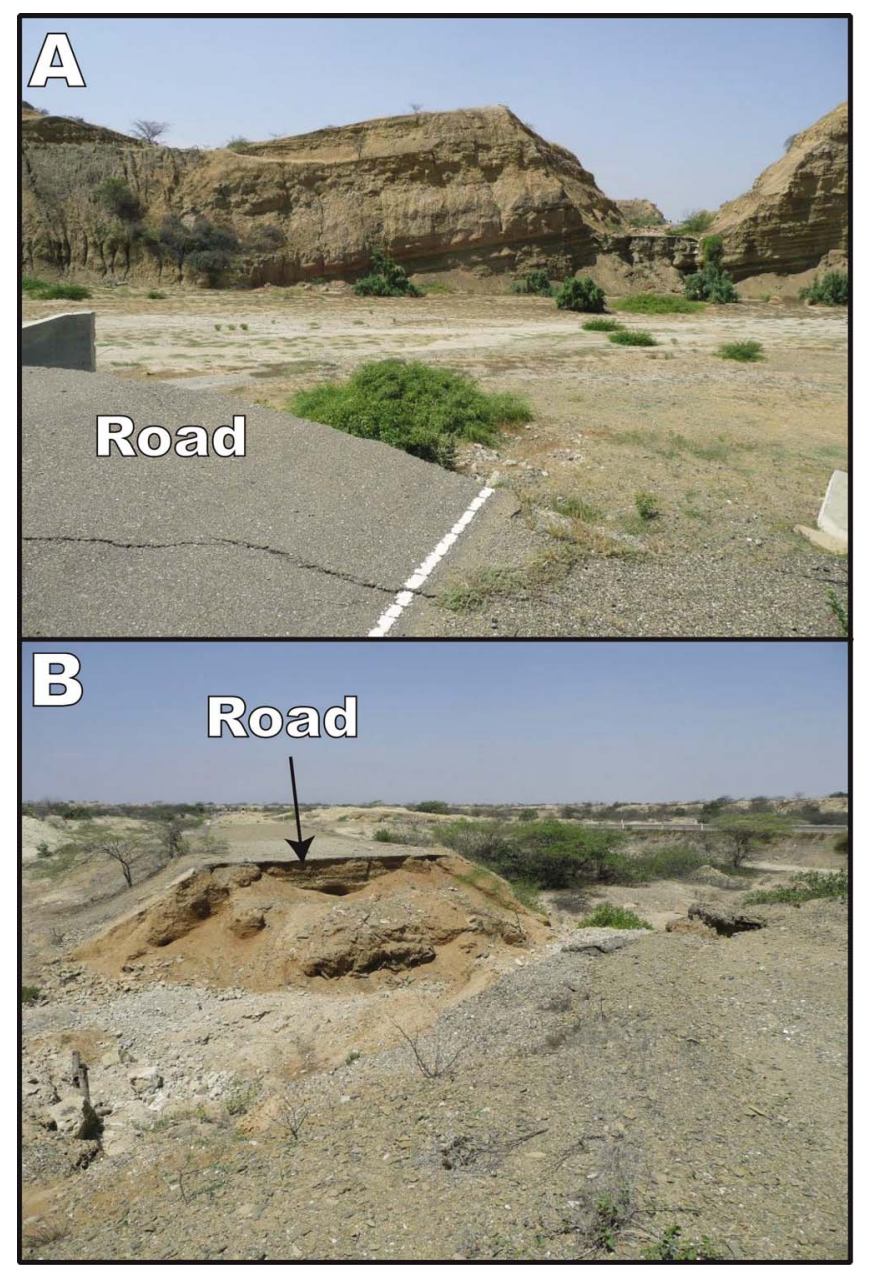

Figure 1. Examples of road and bridge destructions along the Panamerican highway-related to strong rainfalls (a) East of Talara; (b) Southeast of Cabo Blanco. Most of these destructions resulted from floods that occurred during the last very strong El Niño event of 1997-98. (Photos L. Ortlieb, May 2010.)

to the NE of the cape were carved by coastal erosion. The Cabo Blanco cliffs occur in the sandstones of the Eocene Talara Formation [e.g., Shepherd and Moberly, 1981]. We disagree on the interpretation of such features as wave, surf or tidal notches [van de Plassche, 1986] to account for differential erosion in alternating beds with slightly distinct sedimentological and petrographical characteristics (the socalled structurally controlled notch). It seems that the subhorizontal bedding of the Talara Fm in the area (Figure 2) led Bourgois et al. [2007] to interpret that notches produced by meteoric erosion on a sedimentary horizontal bedding were derived by successive relative stands in Recent sea level. A closer look at the geometry of the notches leaves no doubts regarding the fact that the notches are structurally controlled by stratigraphy, and cannot have been imprinted by recent coastal erosion or dissolution (Figure 2). We consider that these features formed above sea level by erosion of weaker strata followed by cliff collapse due to undermining.

\section{Marine Terraces and Paleontological Arguments}

[5] From the point of view of tectonics, marine-terrace sequences are created by two processes [Lajoie, 1986]: (1) coseismic uplift and (2) long-term, interseismic uplift. Coseismic uplift is described only from the Holocene and results in staircase topography that reaches inland a few hundreds of meters and where the height difference between each step is usually on the scale of $3-5 \mathrm{~m}$. These factors have not been consistent with eustatic sea level change since ca. 6000 years ago [Ota and Yamaguchi, 2004]. Quaternary sea level fluctuations and more particularly interglacial periods (stage and substage) superimposed on a rising coastline result in staircase topography corresponding to a marineterrace sequence where the height difference between each step is on the order of about $10 \mathrm{~m}$ reaching several kilometers inland. Along a $200 \mathrm{~km}$ long stretch of coast in northwestern Peru, the landscape is characterized by the widespread development of marine terraces superceeded by wide, compound, marine surfaces called "tablazos" that can reach $>30 \mathrm{~km}$ inland [e.g., Macharé and Ortlieb, 1994]. For the most recent published map see Pedoja et al. [2006] South of Los Organos village (i.e., less than $5 \mathrm{~km}$ north of Cabo Blanco). Pedoja [2003] and Pedoja et al. [2006] described a sequence (sequence $\mathrm{Va}$ in their Figure 7 ) of two marine terraces (T1 at $31 \pm 1 \mathrm{~m}$ and $\mathrm{T} 2$ at $60 \pm 10 \mathrm{~m}$ ) superceded by the Mancora Tablazo. The distal edge of Mancora Tablazo in this area has been measured at $160 \mathrm{~m}$, and its upper shoreline angle at $305 \pm 10 \mathrm{~m}$. In the work of Pedoja [2003], IRSL dating of T1 deposits (Sample NP2, Table 16) and the upper part of the Mancora Tablazo (sample NP3, table) yielded apparent ages of $74 \pm 22 \mathrm{ka}$ (T1) and $160 \pm 12$ (Mancora Tablazo), respectively. Based on these results, a possible correlation of $\mathrm{T} 1$ with the last interglacial maximum was proposed. The results of the NP3 sample were dismissed because of weak constraints by the annual dose rate, leading Pedoja [2003] to conclude that IRSL dating was unreliable in this area. Surprisingly, these geochronological results are considered as correct ages by Bourgois et al. [2007], who added some confusion by attributing the misleading result of the NP3 IRSL dating not to the Mancora Tablazo [Pedoja, 2003] but to El Nuro Member which was defined by DeVries [1986, 1988] as part of the late Pliocene Taime Formation.

[6] Furthermore, some of the molluskan fossils from the Mancora Tablazo and the underlying Taime Formation lithostratigraphic units are extinct, and their ranges are known from northern Peru [DeVries, 1986, 1988], southern Peru [Muizon and DeVries, 1985; DeVries, 2001, 2003; DeVries and Vermeij,1997], and Chile [Philippi, 1897; Herm, 1969]. The fossil evidence for a late Pliocene/early Pleistocene age for the Taime Formation and Mancora Tablazo is compelling. Extinct mollusks are found in the Carrizo Member of the Taime Formation in the Talara Basin, correlating near-basal strata of the Hornillos Formation in the Sechura Basin, with the Mancora Tablazo. We tend to consider that they should have at least stated that 


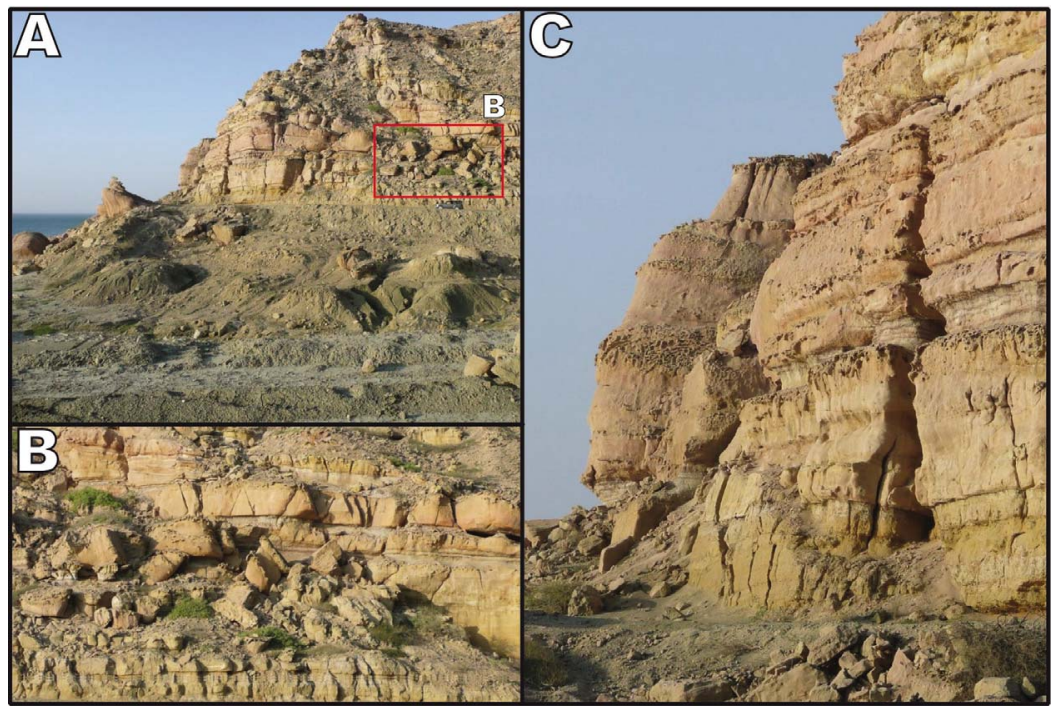

Figure 2. "Disputed" outcrops. (a) Locality illustrated by Bourgois et al. [2007, Figures 5A and 9], immediately to the NE of Cabo Blanco. The car in the middle right of the photograph gives the scale. (b) Close-up of the "notches" which we interpret as resulting from differential erosion of beds of different lithologies. (c) Frontal view of the base of the cliff, with subhorizontal bedding of the Talara formation which induced Bourgois et al. [2007] to erroneously consider that the erosion notches were produced by successive stands of sea level in the latest Quaternary. (Photos L. Ortlieb, May 2010.)

some of the lithostratigraphic units they recognized in the field had been assigned much older ages than they hypothesized.

\section{The ${ }^{10}$ Be Methods and Ages}

[7] From Bourgois et al. [2007], we observe the following irregularities: (1) ${ }^{10} \mathrm{Be}$ cosmogenic nuclide data must state the topographic shielding, which is important to take into account when samples are collected on or below cliffs of significant height (a 50\% correction in the case of vertical shielding, such as exists for this site, would produce an age twice as old), (2) parameters used for the calculation of the production rate are not stated: Bourgois et al. [2007, p. 8] write: "To date the surface, we subtract these concentrations to those of superficial samples collected at the same place."; this is apparently not the procedure used for the calculations of Table 1, at least for N02 and N03, (3) sampling is not always described (it lacks a photo for N05-N06-N07) or shows a poorly reliable strategy: sample N02 was taken on a fallen block with complicated exposure history, (4) some blank samples are presented (with stars), but the authors never discuss their implication, especially when blank samples show the same concentration as surface samples (e.g., N03-N04) (nor do Bourgois et al. [2007] discuss the assumption of negligible erosion and the ages being minimum estimates: they always treat them as quite confident results, even if the age estimate is a single value), and lastly (5) we wonder whether their Figure 11 was reviewed by any specialist in cosmogenic nuclides. In situ ${ }^{10} \mathrm{Be}$ ages are treated as atmospheric ${ }^{14} \mathrm{C}$. The axis specifies "Time $\left({ }^{14} \mathrm{C}\right.$ kyr $)$ " and there is an axis shown for calibrated data. Apparently the ${ }^{10} \mathrm{Be}$ data have been calibrated, which does not mean anything.

\section{Geophysical Inconsistencies on Subduction Seismic Processes and Coseismic Permanent Uplift}

[8] Seismic hazard assessments for subduction zone earthquakes are based on the rupture area modeled and constrained by geodetic data. This sometimes includes coastal coseismic subsidence or uplift as estimated from elevation studies [Sieh et al., 2008]. Bourgois et al. [2007] propose a coseismic origin for successive staircase marine surfaces and notches and thus the occurrence of exceptional $M>8$ earthquakes in northern Peru. If mega events had occurred during the last $20 \mathrm{ka}$ in northern Peru or southern Ecuador, additional sequences of repeated uplifts similar in age to those described by Bourgois et al. [2007] should be identified north and south of the described area. Despite systematic exploration of the coastal area during his $\mathrm{PhD}$ research, Pedoja [2003] found no similar sequences. Similarly, due to both the high magnitude proposed for the deduced earthquakes and their frequent recurrence (16 steps, i.e., 16 times over the Holocene), the extension of such ruptures and their existence also should be recognizable inland (e.g., incised continental markers in coastal valleys, or paleotsunami deposits). These features have not been recognized [Ortlieb and Macharé, 1993; Rogers et al., 2004]. The large deltaic coastal plain built at the mouth of the Rio Chira, (immediately to the south of Talara), as well as the morphological and altimetric disposition of sets of beach ridges cannot be linked with a significant uplift during the last 6000 years [Ortlieb et al., 1995]. This relative coastal stability during the second half of the Holocene is clearly at odds with the 
interpretation of Bourgois et al. [2007]. Finally, during a complete cycle, most of the coseismic vertical movements are attenuated and vanish almost entirely during the post seismic and interseismic phases, leaving less than $5 \%$ of the instantaneous coseismic uplift preserved after several seismic cycles [Savage, 1983]. In the Cabo Blanco area, had nine meters of coseismic uplift been preserved over successive seismic cycles up to the present time, it would require a minimum of $180 \mathrm{~m}$ of instantaneous vertical coseismic uplift at the time of the giga earthquake. This is more than 2 orders of magnitude higher than the present-day highest coseismic observations (Sumatra) and models (Chile, 1960): this is simply unrealistic.

\section{Conclusions}

[9] We reiterate what previous workers have demonstrated: (1) the oldest marine terrace, the Mancora Tablazo [DeVries, 1988; Macharé and Ortlieb, 1994; Pedoja et al., 2006] cannot be as young as $160 \mathrm{ka}$ old, and is most probably older than $2 \mathrm{Ma},(2)$ extinct faunas that have been recognized as of Late Pliocene in age along a major part of the Pacific coast of South America should not be viewed as young as $160 \mathrm{ka}$. On all these grounds, we reject key parts of the contribution by Bourgois et al. [2007] that deal with supposed impacts of Late Quaternary sea level fluctuations, high-frequency coseismic activity and, finally, extreme uplift rates. The northwestern Peru coastal region has been recognized, for almost a century, as a "classical" slowly uplifted region during Plio-Quaternary times. Much remains to be understood in terms of crustal processes, modalities of the uplift and chronology of events leading to the formation of the large and famous "tablazos." Unfortunately, we fail to believe that relevant information and interpretation were brought to bear on these issues by Bourgois et al. [2007].

\section{References}

Bourgois, J., F. Bigot-Cormier, D. Bourles, R. Braucher, O. Dauteuil, C. Witt, and F. Michaud (2007), Tectonic record of strain buildup and abrupt coseismic stress release across the northwestern Peru coastal plain, shelf, and continental slope during the past $200 \mathrm{kyr}$, J. Geophys. Res., 112, B04104, doi:10.1029/2006JB004491.

Carranza, L. (1891), Contracorriente maritima observada en Payta y Pacasmayo, Bol. Soc. Geogr. Lima, 1, 344-345.

DeVries, T. J. (1986), The geology and paleontology of Tablazos in northwest Peru, Graduate thesis, 671 pp., Ohio State Univ., Columbus.

DeVries, T. J. (1988), The geology of late Cenozoic marine terraces (tablazos) in northwestern Peru, J. South Am. Earth Sci., 1, 121-136, doi:10.1016/0895-9811(88)90030-2.

DeVries, T. J. (2001), Contrasting patterns of Pliocene and Pleistocene extinctions of marine mollusks in western North and South America, Geol. Soc. Am. Abstr. Programs, 33, A-35.

DeVries, T. J. (2003), Acanthina Fischer von Waldheim, 1807(Gastropoda: Muricidae), an ocenebrine genus endemic to South America, Veliger, 46, 332-350.

DeVries, T. J., and G. J. Vermeij (1997), Herminespina: New genus of Neogene muricid gastropod from Peru and Chile, J. Paleontol., 71, 610-615.

Eguiguren, D. V. (1894), Las Lluvias de Piura, Bol. Soc. Geogr. Lima, 4, $241-258$.

Herm, D. (1969), Marines Pliozän und Pleistozän in Nord- und MittelChile unter besonderer Berücksichtigung der Entwicklung der MolluskenFaunen, Zitteliana, 2, 1-159.

Lajoie, K. R. (1986), Coastal tectonics, in Active Tectonics, pp. 95-124, Natl. Acad., Washington, D. C.
Macharé, J., and L. Ortlieb (1994), Morfoestratigrafia de los tablazos del noroeste peruano: Neotectonica y fluctuaciones del nivel del mar, paper presented at VIII Congreso Peruano de Geologia, Soc. Geol. del Perú, Lima.

Muizon, C., and T. J. DeVries (1985), Geology and paleontology of the Pisco Formation in the area of Sacaco, Peru, Geol. Rundsch., 74, 547-563, doi:10.1007/BF01821211.

Ortlieb, L., and J. Macharé (1993), Former El Niño events: Records from western South America, Global Planet. Change, 7, 181-202, doi:10.1016/0921-8181(93)90049-T.

Ortlieb, L., M. Fournier, and J. Macharé (1995), Beach ridges and major Late Holocene El Niño events in northern Peru, J. Coastal Res., 17, 109-117.

Ota, Y., and M. Yamaguchi (2004), Holocene coastal uplift in the western Pacific Rim in the context of late Quaternary uplift, Quat. Int., 120, $105-117$.

Pedoja, K. (2003), Les terrasses marines de la marge Nord Andine (Equateur et Nord Pérou): Relations avec le contexte géodynamique, Ph.D. thesis, 350 pp., Université Pierre et Marie Curie, Paris.

Pedoja, K., L. Ortlieb, J. F. Dumont, M. Lamothe, B. Ghaleb, M. Auclair, and B. Labrousse (2006), Quaternary coastal uplift along the Talara Arc (Ecuador, Northern Peru) from new marine terrace data, Mar. Geol., 228, 73-91, doi:10.1016/j.margeo.2006.01.004.

Philippi, R. A. (1897), Fósiles Terciarios i Cuartarios de Chile, 312 pp. Brockhaus, Leipzig, Germany.

Quinn, W. H., V. T. Neal, and S. Antúnez de Mayolo (1987), El Niño occurrences over the past four and a half centuries, J. Geophys. Res., 92, 14,449-14,461, doi:10.1029/JC092iC13p14449.

Richter, M. (2005), Vegetation development before, during, and after El Niño 1997/98 in northwestern Perú, Lyonia, 8, 19-27.

Rogers, S. S., D. H. Sandweiss, K. A. Maasch, D. F. Belknap, and P. Agouris (2004), Coastal change and beach ridges along the northwest coast of Peru: Image and GIS analysis of the Chira, Piura, and Coloane beach-ridge plains, J. Coastal Res., 204, 1102-1125, doi:10.2112/030006R.1.

Savage, J. C. (1983), A dislocation model of strain accumulation and release at a subduction zone, J. Geophys. Res., 88, 4984-4996.

Schütte, K. (1968), Untersuchungen zur Meteorologie und Klimatologie des El Niño-Phänomens in Ecuador und Nord Peru: Bonner Meteorologische Abhandlungen, v. 9.

Schwerdfeger, W. (1976), Climates of Central and South America, in World Survey of Climatology, vol. 12, edited by H. E. Landsberg, 532 pp., Elsevier Sci., Amsterdam.

Shepherd, G., and R. Moberly (1981), Coastal structure of the continental margin, northwest Peru and southwest Ecuador, Geol. Soc. Am. Bull., 154, 351-391.

Sieh, K., D. H. Natawidjaja, A. J. Meltzner, C.-C. Shen, H. Cheng, K.-S. Li, B. W. Suwargadi, J. Galetzka, B. Philibosian, and R. L. Edwards (2008), Earthquake supercycles inferred from sea-level changes recorded in the corals of west Sumatra, Science, 322, 1674-1678, doi:10.1126/ science. 1163589 .

Spruce, R. (1864), Notes on the Valleys of Piura and Chira in Northern Peru and on the Cultivation of Cotton Therein, 81 pp., Eyre and Spottswoodie, London.

van de Plassche, O. (1986), Sea-Level Research: A Manual for the Collection and Evaluation of Data, 618 pp., Geo Books, Norwich, U. K.

L. Audin, Institut des Sciences de la Terre, UMR 5275, CNRS/INSU/ OSUG, IRD/UR/IFSTTAR, U. de Savoie, Université Joseph Fourier, F-38000 Grenoble, France.

T. J. Devries, Burke Museum of Natural History and Culture, University of Washington, Seattle, WA 98195, USA.

J. Machare, Applied Geoscience Division, Exploandes SAC, Av. Javier Prado Este 1238, San Isidro, Lima, Perú.

L. Ortlieb, Laboratoire d'Océanographie et du Climat, Expérimentation et Analyses Numériques LOCEAN, IRD-CNRS-MNHN, Université Pierre et Marie Curie, F-93143 Paris, Bondy CEDEX, France.

K. Pedoja, Laboratoire de Morphodynamique Continentale et Côtière, CNRS, Université de Caen, F-14000 Caen, France. (kevin.pedoja@ unicaen.fr)

V. Regard, Laboratoire Géosciences Environnement Toulouse, CNRS/ IRD, Earth and Planetary Sciences Department, Université Paul SabatierToulouse III, F-31400 Toulouse, France. 